\title{
The relationship between fluorescent, agglutinating, and precipitating antibodies to Candida albicans and their immunoglobin classes
}

\author{
T. LEHNER, HELEN R. BUCKLEY, AND I. G. MURRAY
}

From the Department of Oral Immunology and Microbiology, Guy's Hospital Medical and Dental Schools, London, and the Mycological Reference Laboratory, London School of Hygiene and Tropical Medicine

SYNOPSIS A parallel study of fluorescent, agglutinating, and precipitating antibodies to Candida albicans revealed that precipitating antibodies belong to the IgG class, whereas agglutinating antibodies reside in the IgG, IgM, and IgA classes. The three types as well as the three classes of antibodies were found in Candida endocarditis and mucocutaneous candidiasis. Immuno-absorption studies suggest that the three serological tests estimate antibodies to mannan determinants of Candida albicans.

A variety of tests for antibodies to Candida have been used in different laboratories and the most common of these are agglutinating tests (Winner, 1955; Murray, Buckley, and Turner, 1969), precipitating tests (Murray et al, 1969; Stallybrass, 1964; Taschdjian, Kozinn, and Caroline, 1964; Chew and Theus, 1967; Pepys, Faux, Longbottom, McCarthy, and Hargreave, 1968), and immunofluorescent tests (Lehner, 1966, 1970; Esterly, 1968). The relationship between these antibodies and their immunoglobulin classes has not been defined, although this is of considerable interest in view of the diverse diagnostic claims made for some of these antibodies. Winner (1955) found that up to $64 \%$ of the apparently uninfected population had agglutinating antibodies to Candida and this led him to question their diagnostic value. Precipitating antibodies, however, have been found predominantly in systemic candidiasis (Stallybrass, 1964; Taschdjian et al, 1964), though others (Chew and Theus, 1967; Pepys et al, 1968) have found them in healthy subjects or in the absence of systemic candidiasis (Murray et al, 1969).

A quantitative relationship between the level of serum antibodies in patients with candidiasis, as compared with carefully selected controls, was established for agglutinins (Comaish, Gibson, and Green, 1963) and for fluorescent antibodies (Lehner, 1966 and 1970). These results suggested that the diagnosis of candidiasis was dependent on the sensitivity and possibly immunoglobulin class of antibodies and that significant titres could be found Received for publication 30 September 1971. to differentiate infection from controls. Indeed, the N aims of this investigation were to compare three methods of antibody estimation with special reference to the immunoglobulin class of antibody.

\section{Patients and Methods}

SERA

The series of 31 samples of blood were divided into three groups.

\section{Group I}

Sera from 10 patients with chronic mucocutaneous candidiasis.

\section{Group II}

Seven sequential sera from three patients who had cardiac surgery and developed Candida endocarditis.

\section{Group III}

Fourteen sequential sera from four patients who N had cardiac surgery without developing endocarditis.

FLUORESCENT ANTIBODY TEST

The indirect technique was used to determine the titre of the specific immunoglobulin class of Candida antibodies by using monospecific IgG, IgA, and $\stackrel{\mathbb{D}}{\rightleftharpoons}$ IgM conjugates as described previously (Lehner, 1966, 1970). Sheep antirabbit serum conjugate (Wellcome reagents) was used to estimate the fluorescent antibody to Candida in the antisera raised in rabbits. The smears were made by using yeast cells of Candida albicans group A, suspended 
in $0.4 \%$ formaldehyde saline. Doubling dilutions of sera from 1 in 2 were made in buffered saline to determine the antibody titre.

\section{AGGLUTINATION TEST}

This was carried out with whole yeast cells of another strain of Candida albicans group $\mathbf{A}$ as described previously (Murray et al, 1969). The agglutination titre was determined by using serially diluted sera.

\section{PRECIPITATION TEST}

The organisms were disrupted by a hydraulic press, centrifuged at $40000 \mathrm{~g}$, and the supernatant was used in a gel diffusion precipitation test(Murray et al, 1969). The results were expressed as positive or negative precipitation reactions. In order to be certain that the strain of Candida albicans group A used in the fluorescent antibody test did not differ from that applied to the agglutination and precipitation reactions, a number of sera were tested in parallel by the fluorescent antibody test with smears prepared from both strains of Candida. Precipitating antibodies to mannan and protein components of the yeast cells were tested by double diffusion tests as described previously (Buckley, Lapa, and Hipp, 1970).

\section{DEAE CELLULOSE CHROMATOGRAPHY}

A pooled serum from four patients with oral candidiasis was fractionated by the method described previously (Levy and Sober, 1960; Lehner, 1969). The resulting three fractions were examined for IgG, IgA, and IgM by immunoelectrophoresis and each fraction was tested for Candida antibodies.
RABBIT ANTIBODY TO CANDIDA ALBICANS

Serum IA was raised by two subcutaneous injections of $260 \mathrm{y}$ of soluble antigen in incomplete Freund's adjuvant at monthly intervals, and the rabbits were bled after three weeks. Serum RAS was raised by intravenous injections of $2 \%$ formalized cells, three times a week for four weeks, and the rabbits were bled one week after the last injection.

\section{IMMUNOABSORPTION}

Antisera IA, RAS, and a serum from a patient with systemic candidiasis, containing antibodies to Candida albicans, were absorbed. One $\mathrm{ml}$ of serum was mixed with $0.4 \mathrm{ml}$ of a Candida suspension,

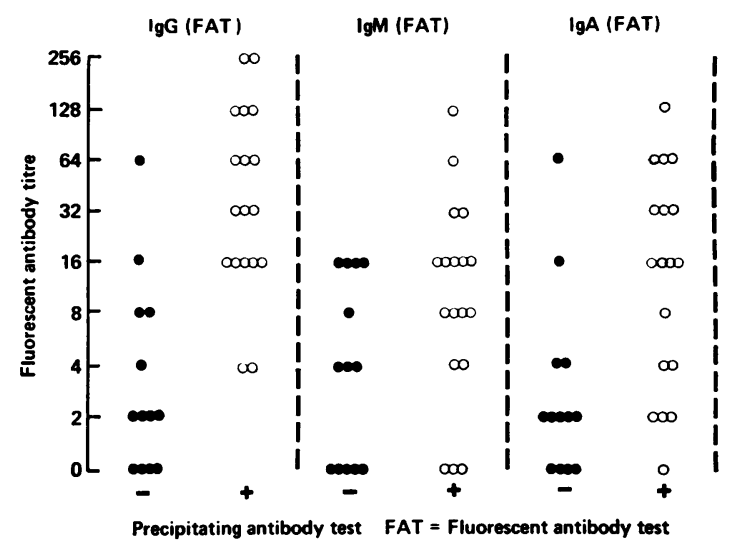

Fig. 1 Comparison of fluorescent and precipitating antibody tests.

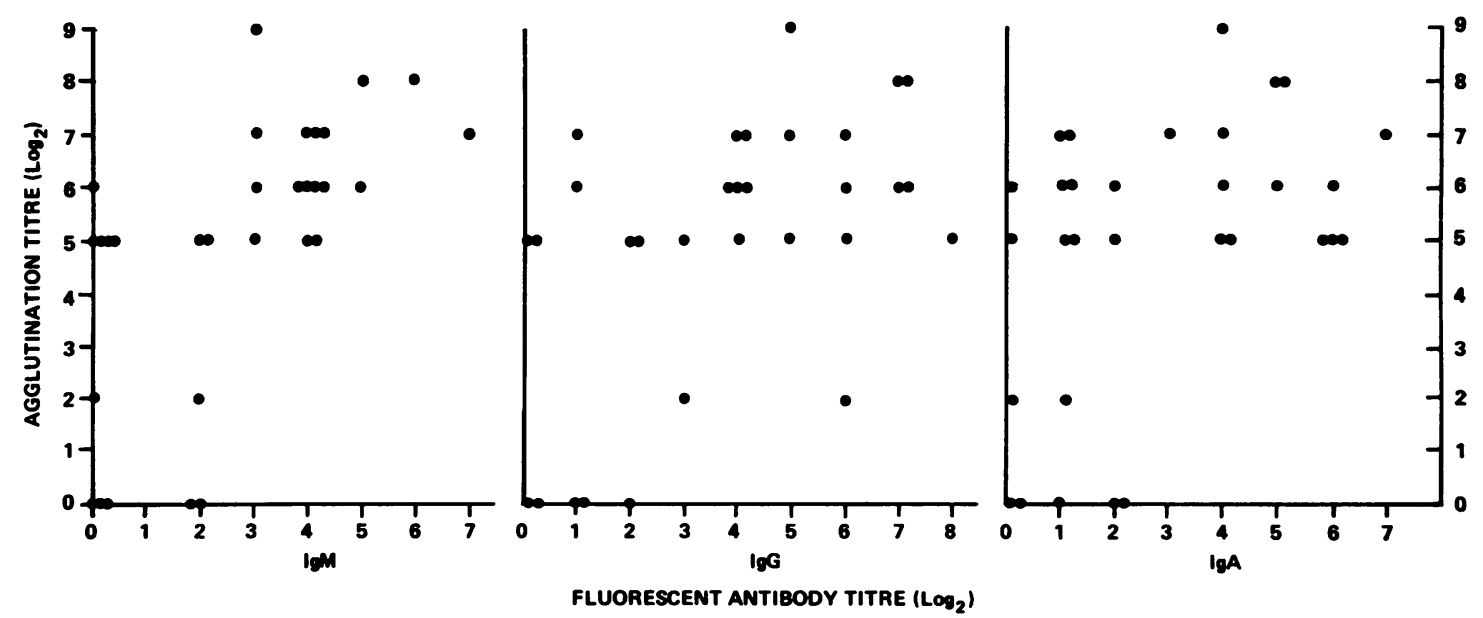

Fig. 2 The relationship between agglutination and fuorescent antibody titres. 
with a PCV of $70 \%$; this was kept at $37^{\circ} \mathrm{C}$ for three hours and then at $4^{\circ} \mathrm{C}$ overnight. The absorbed serum was centrifuged and then reabsorbed. The absorbed and unabsorbed sera were tested by the three methods for Candida antibodies.

\section{Results}

\section{RELATIONSHIP BETWEEN THE IMMUNO-}

GLOBULIN CLASSES OF CANDIDA ANTIBODIES The immunoglobulin class of fluorescent antibodies is compared with precipitating and agglutinating antibodies in Figures 1 and 2. The highest titres were found with the agglutination test up to 1 in 512 , followed by fluorescent antibodies, up to 1 in 256 for IgG, and 1 in 128 for $\operatorname{IgA}$ and IgM. A very significant relationship was established by means of the Chi square test (with Yate's correction) between precipitating and IgG fluorescent antibodies $(P<0.001)$, but not with IgM or IgA. However, agglutinating titres were significantly correlated with all three immunoglobulin classes of fluorescent antibody titres: $\operatorname{IgM}(\mathrm{r}=0.615, \mathrm{P}<0.001)$, IgG $(\mathrm{r}=0.534, \mathrm{P}<0.01), \operatorname{IgA}(\mathrm{r}=0.461, \mathrm{P}<0.01)$. The fluorescent antibody titre against the two strains of Candida albicans was almost identical.
The immunoglobulin class of antibodies was determined directly by using the chromatography fractions (Fig. 3). IgG was found in the first fraction, IgM in the third fraction, and IgA (with some IgG) in the second fraction. The corresponding class of fluorescent antibodies was found in each of these fractions but precipitins were detected only in the IgG fraction. Agglutinins were present mostly in the IgM fraction (titre of $1: 64$ ), to a less extent in IgG $(1: 16)$, and a low titre of $(1: 4)$ was also detected in the IgA fraction.

ANTIBODIES IN SYSTEMIC AND MUCOCUTANEOUS CANDIDIASIS AND IN RABBIT ANTISERA $A$ rise in antibody titre and the appearance of precipitins was found in patients with endocarditis (Table I). This was also present in two of the four patients who did not develop endocarditis, although the fluorescent antibody titre rose only to low levels. The group of patients with chronic mucocutaneous candidiasis revealed significant agglutinating and fluorescent antibodies, and precipitating antibodies were found in six out of 10 patients (Table II). Both rabbit antisera showed agglutinating and fluorescent $N$ antibodies (Table III) but serum IA revealed precipitating antibodies to mannan and protein

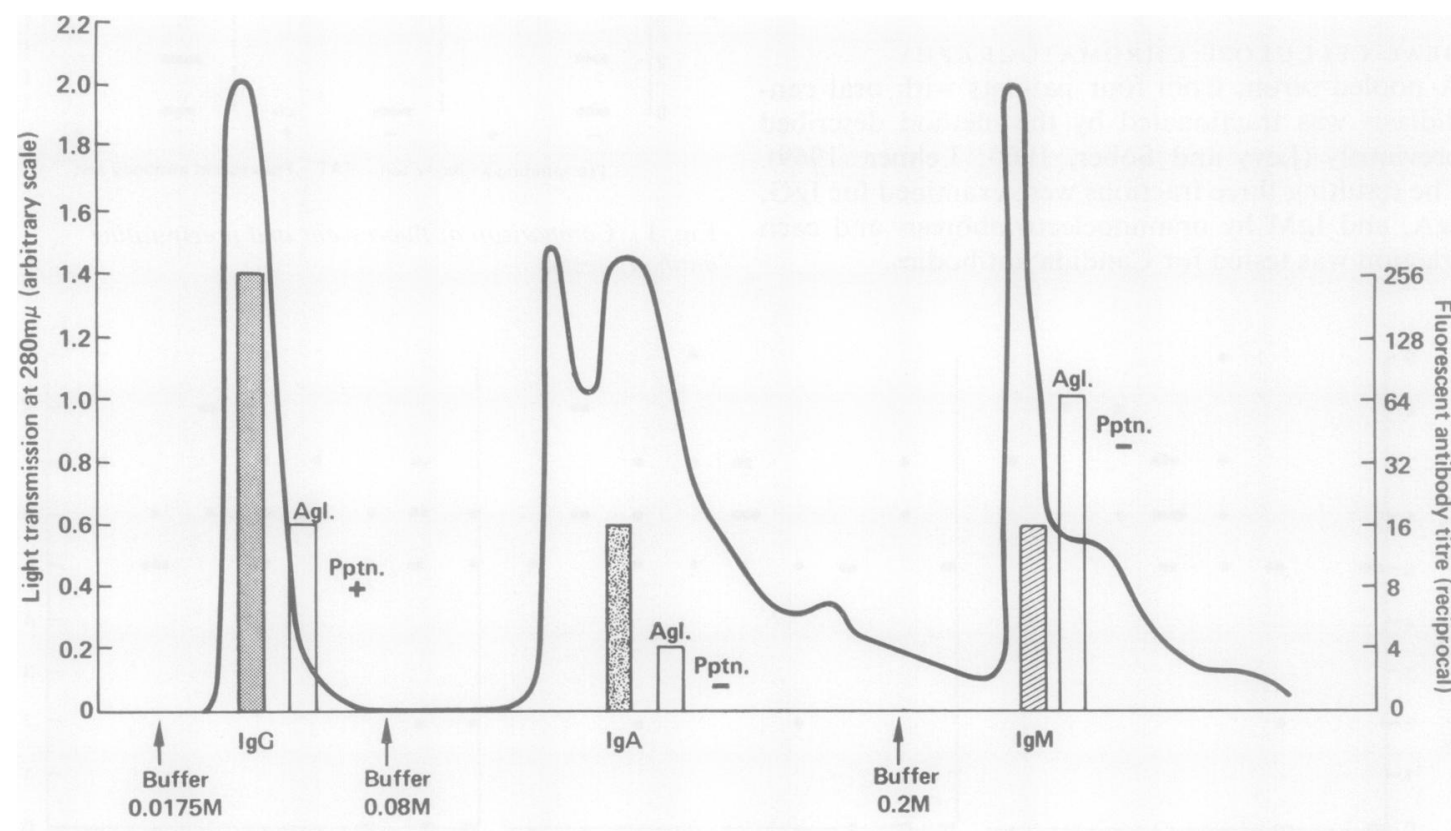

Agl. = agglutinating titre

Pptn. = precipitating antibody

Fig. 3 The distribution of $\operatorname{IgG}, \operatorname{IgA}$, and IgM classes of Candida antibodies, as determined by the fluorescent, agglutination, and precipitation antibody tests with $D E A E$ cellulose chromatography fractions. 


\begin{tabular}{llllll}
\hline Patients & $\begin{array}{l}\text { Pre- } \\
\text { cipitating } \\
\text { Antibody }\end{array}$ & $\begin{array}{l}\text { Agglutinating } \\
\text { Antibody }\end{array}$ & \multicolumn{2}{l}{ Fluorescent Antibody } \\
\cline { 4 - 6 } & & IgG & IgA & IgM \\
\hline
\end{tabular}

\section{With Candida}

Endocarditis

$\begin{array}{lrrrrr}\begin{array}{l}1 \\ \text { (before surgery) }\end{array} & - & 0 & 4 & 2 & 0 \\ \begin{array}{l}\text { 1 a } \\ \text { (after surgery) }\end{array} & + & 128 & 64 & 128 & 8 \\ 2 & + & 256 & 128 & 32 & 32 \\ 3 & + & 256 & 256 & 32 & 64\end{array}$

Without

Endocarditis

1 (before)

1a (after)

2 (befure)

2a (after)

3

$\begin{array}{rr}- & 0 \\ + & 128 \\ - & 0 \\ + & 512 \\ - & 128 \\ - & 0\end{array}$

Table I Comparison of fluorescent, precipitating, and agglutinating antibodies to Candida albicans in patients having cardiac surgery

\begin{tabular}{lllrrr}
\hline Serum & $\begin{array}{l}\text { Precipitating } \\
\text { Antibody }\end{array}$ & $\begin{array}{l}\text { Agglutinating } \\
\text { Antibody }\end{array}$ & \multicolumn{3}{c}{ Fluorescent Antibody } \\
\cline { 3 - 6 } & & & IgG & IgA & IgM \\
\hline 1 & + & 128 & 32 & 16 & 128 \\
2 & + & 64 & 16 & 2 & 8 \\
3 & + & 64 & 128 & 32 & 32 \\
4 & + & 64 & 128 & 16 & 16 \\
5 & + & 32 & 64 & 16 & 1 \\
6 & + & 32 & 256 & 64 & 0 \\
7 & - & 32 & 8 & 2 & 0 \\
8 & - & 32 & 0 & 64 & 16 \\
9 & - & 4 & 64 & 0 & 0 \\
10 & - & 4 & 8 & 2 & 4 \\
\hline
\end{tabular}

Table II Comparison of fluorescent, precipitating, and agglutinating antibodies in patients with chronic mucocutaneous candidiasis

components, whereas serum RAS had only antibodies to mannan.

\section{IMMUNOABSORPTION}

After absorption of the three antisera the precipitating and fluorescent antibodies were undetectable except for a titre of 1 in 8 (no. 6; Table III) and the agglutinating antibodies were depressed to $\leqslant 1$ in 16 .
These findings were particularly significant as antibodies to mannan components were absent, though antibodies were present to protein components in the absorbed sera (nos. 2 and 4; Table III). Antiserum RAS (no. 5; Table III) showed antibodies only to mannan components and the highest agglutinating and fluorescent antibody titres. It appears from these results that mannan and not protein antibodies are responsible for the agglutination and fluorescent reactions.

\section{Discussion}

Direct testing of the immunoglobulin fractions of human serum has revealed that precipitins to Candida belong to the IgG class and that they are very significantly related to the IgG class of fluorescent antibodies $(P<0.001)$. This is consistent with the view that IgG antibodies are very effective precipitins (Pike, 1967). Agglutinins, however, were found in highest titre in the IgM fraction (1:64) of fluorescent antibodies $(r=0.615, P<0.001)$. Agglutinating antibodies were also detected in the IgG (1:16) and IgA (1:4) fractions, and were significantly related to the IgG $(r=0.534, \mathrm{P}<0.01)$ and $\operatorname{IgA}(\mathrm{r}=0.461, \mathrm{P}<0.01)$ fluorescent antibodies. Although the IgA chromatography fraction contained a small amount of IgG, there was no detectable IgG in the IgA fluorescent conjugate, so that agglutinating antibodies to Candida may belong to the $\operatorname{IgA}$ in addition to the IgM and IgG classes. Thus, the agglutination test for Candida estimates the three major classes of antibodies and the high agglutination titre may represent a summation of the IgM, IgG, and IgA titres. Indeed, the agglutination titre showed the best correlation with the three summated fluorescent antibody titres $(r=0.695, P<0.001)$. These results are consistent with the findings of others that for agglutination smaller amounts of IgM than IgG are required and that agglutinating activity is shown by the IgA class of antibodies (Pike, 1967).

A differential diagnosis could not be made between systemic and mucocutaneous candidiasis by any one of the three immunological tests. Precipitins were

\begin{tabular}{|c|c|c|c|c|c|c|c|}
\hline \multicolumn{2}{|c|}{ Serum } & \multicolumn{2}{|c|}{ Precipitating Antibody to: } & \multirow{2}{*}{$\begin{array}{l}\text { Agglutinating } \\
\text { Antibody }\end{array}$} & \multicolumn{3}{|c|}{ Fluorescent Antibody } \\
\hline & & \multirow{2}{*}{$\begin{array}{l}\text { Protein } \\
+\end{array}$} & \multirow{2}{*}{$\begin{array}{l}\text { Mannan } \\
+\end{array}$} & & \multirow{2}{*}{$\begin{array}{l}I g G \\
32\end{array}$} & \multirow{2}{*}{$\frac{I g M}{16}$} & \multirow{2}{*}{$\frac{\operatorname{IgA}}{16}$} \\
\hline 1 & Human 562 & & & 128 & & & \\
\hline 2 & Human 562 absorbed & + & - & $<16$ & 0 & 0 & 0 \\
\hline 3 & Rabbit 1A & + & + & $>100$ & & $\begin{array}{c}\gamma \text { glo } \\
32\end{array}$ & \\
\hline 4 & Rabbit 1 A absorbed & + & - & $<16$ & & 0 & \\
\hline 5 & Rabbit RAS & - & + & $>1000$ & & 256 & \\
\hline 6 & Rabbit RAS absorbed & - & - & 16 & & 8 & \\
\hline
\end{tabular}

Table III Comparison of four types of antibody in two rabbit and one human antisera to Candida albicans before and after absorption 
found in six out of 10 patients with chronic mucocutaneous candidiasis and this differed from other results (Stallybrass, 1964; Taschdjian et al, 1964). It is now very likely that the specificity ascribed to precipitins can be accounted by their belonging to the IgG class, unlike agglutinins that are found in the $\operatorname{IgM}, \operatorname{IgG}$, and $\operatorname{IgA}$ classes.

In the three patients with Candida endocarditis precipitins and raised agglutinating and fluorescent antibody titres were found. This was particularly evident in the patient in whom serum antibodies could be estimated before and after endocarditis developed (no. 1; Table I). An unusual feature in this patient was that the IgM class of fluorescent antibodies rose only from 0 to 8 , though IgA antibodies rose from 2 to 128 . The appearance of precipitins and a rise of agglutinating titre from 0 to 128 and to 512 in two out of four patients who have undergone cardiac surgery without developing endocarditis could not be interpreted satisfactorily. It is of some interest that the fluorescent antibody test has not shown a corresponding rise in titre in these patients and reached only IgG levels of $1: 16$ and $1: 32$, and IgM of $1: 16$. This suggests that the immunofluorescent test is more reliable than the precipitating and agglutinating tests and that a rise in IgG fluorescent antibody titres to $\geqslant 1: 64$ should be considered as evidence in favour of the diagnosis of systemic candidiasis.

The results of the absorption studies suggest that the present serological tests estimate antibodies to mannan determinants. Thus, high titres of agglutinating and fluorescent antibodies were found in the presence of precipitating antibodies to mannan determinants and absence of protein determinants (Table III). Absorption of antibodies to mannan determinants from antisera in which antibodies to protein determinant were left unabsorbed was associated with a loss of or a significant fall in agglutinating and fluorescent antibodies. Mannan antibodies were also recorded in precipitation tests by others (Chew and Theus, 1967; Pepys et al, 1968). As mannans are probably cell wall components of Candida (Kessler and Nickerson, 1959; Kemp and
Solotorovsky, 1964), and may reside on the surface of yeast cells (Hasenclever and Mitchell, 1964), they would be directly accessible to whole cell agglutination and to antibody binding in the immunofluorescent test.

We wish to thank Mr R. G. Ward for his technical assistance and the Medical Illustration and Photography Departments of Guy's Hospital Medical School for the illustrations.

\section{References}

Buckley, H. R., Lapa, E. W., and Hipp, S. S. (1970). Immunological significance of some antigens of Candida albicans. In Proceedings of the 5th International Congress of Infectious Diseases, Vienna.

Chew, W. H., and Theus, T. I.. (1967). Candida precipitins. J. Immunol. 98, 220-224.

Comaish, J. S., Gibson, B., and Green, C. A. (1963). Candidiasis: serology and diagnosis. J. invest. Derm., 40, 139-142.

Esterly, N. B. (1968). Serum antibody titers to Candida albicans utilizing an immunofluorescent technic. Amer. J. clin. Path., 50, 291-296.

Hasenclever, H. F., and Mitchell, W. O. (1964). A study of yeast surface antigens by agglutination inhibition. Sabouraudia, 3, 288-300.

Kemp, G., and Solotorovsky, M. (1964). Localisation of antigens in mechanically disrupted cells of certain species of the genera Candida and Torulopsis. J. Immunol., 93, 305-314.

Kessler, G., and Nickerson, W. J. (1959). Glucomannan-protein complexes from cell walls of yeasts. J. biol. Chem., 234, 2281-2285.

Lehner, T. (1966). Immunofluorescence study of Candida albicans in candidiasis carriers and controls. J. Path. Bact., 91, 97-104.

Lehner, T. (1969). Characterization of mucosal antibodies in recurrent aphthous ulceration and Behcet's syndrome. Arch. oral Biol., 14, 843-853.

Lehner, T. (1970). Serum fluorescent antibody and immunoglobulin estimations in candidosis. J. med. Microbiol., 3, 475-481.

Levy, H. B., and Sober, H. A. (1960). A simple chromatographic method for preparation of gamma globulin. Proc. Soc. exp. Biol.' (N.Y.), 103, 250-252.

Murray, I. G., Buckley, H. R., and Turner, G. C. (1969). Serological evidence of Candida infection after open-heart surgery. J. med. Microbiol., 2, 463-469.

Pepys, J., Faux, J. A., Longbottom, J. L., McCarthy, D. S., and Hargreave, F. E. (1968). Candida albicans precipitins in respiratory disease in man. $J$. Allergy, 41, 305-318.

Pike, R. M. (1967). Antibody heterogeneity and serological reactions Bact. Rev., 31, 157-174.

Stallybrass, F. C. (1964). Candida precipitins. J. Path. Bact., 87, 89-97.

Taschdjian, C. L., Kozinn, P. J., and Caroline, L. (1964). Immune studies in candidiasis. III. Precipitating antibodies in systemic candidiasis. Sabouraudia, 3, 312-320.

Winner, H. I. (1955). Study of Candida albicans agglutinins in human sera. J. Hyg. (Lond.), 53, 509-512. 